\title{
Developing young scientists. Really?
}

Delivering the keynote address at the third Science Forum South Africa on 7 December 2017, Deputy President Cyril Ramaphosa placed considerable emphasis on the importance of developing young scientists as drivers of growth and innovation. To do so is important not just for the well-being of young people (in reaching their dreams), he told his audience, but for the well-being of South Africa and the continent for the success of the National Development Plan, the United Nations' Sustainable Development Goals, the general enhancement of science and knowledge and (among many other issues) food security.

Two days later, The Economist carried a startling cover: a flag-patterned snake, pronouncing 'The corruption of South Africa' and pointing out, in its major leader, that

$$
\begin{aligned}
& \text { Under President lacob Zuma, the state is failing. } \\
& \text { Contracts are awarded through bribes and } \\
& \text { connections; ruling party members murder each } \\
& \text { other over lucrative government jobs; crooks } \\
& \text { operate with impunity. }
\end{aligned}
$$

And in the time between, on 8 December, the South African High Court in Pretoria ruled that the country's National Director of Public Prosecutions must vacate his position, as his appointment had been made by a 'conflicted' President Zuma. The Court further ruled that the Deputy President must appoint the National Director's successor.

In such a daunting context, what foundations need to be in place to develop young scientists? There are three essentials - fundamental preconditions for ensuring that South Africa is able to develop young scientists (or young economists, or new teachers, for that matter) which are: a pipeline of well-educated children who will become the next generation of knowledge producers; a set of strong appropriate institutions; and serious investment in research. Do we, as a country, have these three pre-requisites in place?

The pipeline? There is, of course, a pipeline of young people who will leave school well-educated and in line to be scientists, economists, teachers, and other essential role players in the national economy. But it is a severely restricted pipeline that, inevitably, excludes the hundreds of thousands of young people who should be well-educated and should be potential contributors to the country's success but who are not and who will not be. The most recent Progress in International Reading Study (PIRLS), undertaken in 2016, reveals that $78 \%$ of South African Grade 4 learners (that is, 10 to 11 year olds) cannot read for meaning - the lowest score in the PIRLS results worldwide. This means that they are unable to locate and retrieve explicitly stated information or make straightforward inferences about events and reasons for actions reported in texts.

Numeracy studies undertaken with Grade 5 and Grade 9 learners the year before the PIRLS research (i.e. 2015) by the Trends in International Mathematics and Science Study are revealing. For Grade 5 learners, South Africa was placed 47th out of 48 participating countries; Grade 9 learners placed South Africa at 38th of 39 countries in the study. What is worse is that the results within South Africa are differentiated by geographical and social factors (translating most often into ethnicity), meaning that the largest proportion of the underperforming students are also the most deserving of opportunities after school. In short, the pipeline is both restricted and discriminatory - and severely ill-suited to developing young people who seek to gain valued skills.

Strong, appropriate institutions? Francis Fukuyama makes the importance of strong institutions in society clear:

\begin{abstract}
..if you don't get the politics right - and by politics I don't just mean the short-term political decisions, but the actual institutions around which societies are organised - then you're not going to have economic growth, you are not going to have the right kind of social development and you're not going to have a just society. ${ }^{2}$
\end{abstract}

These actual institutions are, amongst others, the institutions established under Chapter 9 of the South African Constitution - and, of course, universities. Jonathan Jansen is of the view that South African universities face a range of challenges that, if not addressed, will change their nature for the worse. ${ }^{3}$ The issue of fees versus free education (and hence the matter of institutional income) has been so defectively managed at the very highest levels that some universities will face the prospect of no or very limited income for the first quarter of this year. In short, universities face both intellectual and material challenges that do not auger well for their strength unless there are major shifts away from current trends and circumstances.

Serious investment in research? South Africa has one of the lowest levels of public investment in research among comparable countries - in 2015 the expenditure amounted to $0.77 \%$ of GDP which accounted for about $43 \%$ of gross expenditure on research and development (GERD). By way of comparison, the Turkish GERD stands at $1.06 \%$ of GDP while for China the figure is $2.07 \%$. The local figure by contrast is low - and the National Research Foundation (NRF) recently drastically cut its funding for rated researchers, by as much as $90 \%$ in some instances, claiming that the funds were never intended to be real research monies but incentives to encourage scientists to apply for rating. Some research projects or plans have been thrown into disarray, students associated with funded research projects will no longer receive support for their degrees next year, and other funders who have given money on the grounds that the NRF is providing some of what is needed will have to be placated. Universities are scrambling for a helpful response, and a wide spread sense of demoralisation and anger has set in.

Funding aimed at expanding serious scientific research and new knowledge, some of which can be applied to improve social and economic conditions in the country therefore remains limited and highly contested. This funding is also then not benefitting a new generation of young scientists.

All told, then, none of the three foundations needed to enable the development of science and scientists is securely in place. Of the three, only one (investing in research and development) falls to the state department - the Department of Science and Technology - that works consistently to change these adverse circumstances. For the rest, it is the general condition of gloom that currently prevails.

\section{References}

1. The choice that could save South Africa, or wreck it. The Economist. 2017 December 9. Available from: https://www.economist.com/news/ leaders/21732114-avoid-dire-two-decade-dynasty-dysfunction-southafricas-ruling-anc-should-ditch

2. Fukuyama F. The origins of political order. Mapungubwe Institute for Strategic Reflection Public Lecture 2013. Available from: http://www.mistra. org.za/Media/Speeches/Pages/The-Origins-of-Political-Order-by-FrancisFukuyama.aspx

3. Jansen J. As by fire: The end of the South African university. Cape Town: Tafelberg; 2017 